\title{
Characterization of a Neochlamydia-like bacterium associated with epitheliocystis in cultured Arctic charr Salvelinus alpinus
}

\author{
Andrew Draghi II ${ }^{1}$, Julie Bebak ${ }^{2,6, *}$, Vsevolod L. Popov ${ }^{3}$, Alicia C. Noble ${ }^{2}$, \\ Steven J. Geary ${ }^{1,4}$, A. Brian West ${ }^{1}{ }^{1}$ Philip Byrne ${ }^{5}$, Salvatore Frasca Jr. ${ }^{1,4}$ \\ ${ }^{1}$ Department of Pathobiology and Veterinary Science and ${ }^{4}$ Center of Excellence for Vaccine Research, \\ University of Connecticut, Storrs, Connecticut 06269-3089, USA \\ ${ }^{2}$ The Conservation Fund's Freshwater Institute, 1098 Turner Road, Shepherdstown, West Virginia 25443, USA \\ ${ }^{3}$ Electron Microscopy Laboratory, Department of Pathology, The University of Texas Medical Branch, Galveston, \\ Texas 77555-0609, USA \\ ${ }^{5}$ Fisheries and Oceans Canada, Charlottetown, Prince Edward Island C1A 5T1, Canada
}

${ }^{6}$ Present address: US Department of Agriculture Agricultural Research Service, Aquatic Animal Health Research Laboratory, 990 Wire Road, Auburn, Alabama 36832, USA

\begin{abstract}
Infections of branchial epithelium by intracellular gram-negative bacteria, termed epitheliocystis, have limited culture of Arctic charr Salvelinus alpinus. To characterize a bacterium associated with epitheliocystis in cultured charr, gills were sampled for histopathologic examination, conventional and immunoelectron microscopy, in situ hybridization, 16S ribosomal DNA (rDNA) amplification, sequence analysis and phylogenetic inference. Sampling was conducted at the Freshwater Institute (Shepherdstown, West Virginia, USA) during outbreaks of epitheliocystis in April and May 2002. Granular, basophilic, cytoplasmic inclusions in charr gill were shown to stain with Macchiavello, Lendrum's phloxine-tartrazine and Gimenez histochemical techniques. Ultrastructurally, inclusions were membrane-bound and contained round to elongate reticulate bodies that were immunoreactive to an antibody against chlamydial lipopolysaccharide, suggesting the presence of similar epitopes. DNA extracted from gills supported amplification of the most polymorphic and phylogenetically relevant region of the 16S rRNA gene, which had 97 to $100 \%$ identity with several uncultured clinical Neochlamydia spp. (order Chlamydiales) Clones WB13 (AY225593.1) and WB258 (AY225594.1). Sequence-specific riboprobes localized to inclusions during in situ hybridization experiments. Taxonomic affiliation was inferred by distance- and parsimony-based phylogenetic analyses of the 16S sequence, which branched with Neochlamydia hartmannellae in the order Chlamydiales with high confidence. This is the first molecular characterization of a chlamydia associated with epitheliocystis in Arctic charr and the fourth Neochlamydia spp. sequence to be associated with epitheliocystis. Presence of a clinical neochlamydial sequence, first identified from a cat, in Arctic charr suggests a possible mammalian and piscine host range for some environmental chlamydiae.
\end{abstract}

KEY WORDS: Arctic charr · Environmental chlamydiae $\cdot$ Epitheliocystis $\cdot$ In situ hybridization Neochlamydia $\cdot$ Salvelinus $\cdot$ Ultrastructure $\cdot 16$ S ribosomal RNA gene

\section{INTRODUCTION}

Epitheliocystis is an infectious disease of the epithelium of the gill and skin that has been identified in many cultured and wild freshwater and marine fin- fish species (Hoffman et al. 1969, Wolke et al. 1970, Paperna 1977, Bradley et al. 1988, Lewis et al. 1992, Groff et al. 1996, Nylund et al. 1998, Nowak \& Clark 1999, Corsaro \& Greub 2006, Meijer et al. 2006). Agents associated with epitheliocystis have been character- 
ized ultrastructurally (Hoffman et al. 1969, Wolke et al. 1970, Nylund et al. 1998), antigenically (Groff et al. 1996) or, most recently, molecularly (Draghi et al. 2004, Meijer et al. 2006) as chlamydia or chlamydia-like bacteria. Horn \& Wagner (2001) have proposed the term 'environmental chlamydia' to encompass these diverse, and sometimes medically relevant, chlamydiae isolated from environmental sources, while others suggest a more general term, 'novel chlamydia', to include those chlamydiae not members of the Chlamydiaceae (Corsaro \& Greub 2006). In epitheliocystis, infection of branchial epithelium results in formation of intracytoplasmic basophilic granular inclusions that distend the cytoplasm of individual epithelial cells. Host responses to infection vary from non-proliferative, i.e. with little or no reaction or evidence of clinical disease, to proliferative, characterized by hyperplasia of branchial epithelium resulting in clinical signs of respiratory insufficiency (Nylund et al. 1998, Draghi et al. 2004, Meijer et al. 2006). Percent mortality can range from as low as $4 \%$ to as high as $100 \%$ in cultured juvenile fish. Epitheliocystis has been described in several salmonid species, including lake trout Salvelinus namaycush (Bradley et al. 1988), Atlantic salmon Salmo salar (Nylund et al. 1998, Nowak \& Clark 1999), steelhead trout Oncorhynchus mykiss (Rourke et al. 1984) and Arctic charr Salvelinus alpinus (Noble et al. 1999), wherein it has been associated with significant mortality and economic losses.

Classifying bacteria by analysis of $16 \mathrm{~S}$ and $23 \mathrm{~S}$ rDNA genetic sequences in conjunction with phenotypic characteristics can be used to describe and determine the taxonomy of chlamydia (Everett \& Andersen 1997, Everett et al. 1999, Horn et al. 2000, Thao et al. 2003, Draghi et al. 2004, Corsaro \& Greub 2006) and rickettsia (Dumler et al. 2001). Everett et al. (1999) reorganized chlamydial systematics according to their 16S rDNA sequence identity, creating 4 families, Chlamydiaceae, Parachlamydiaceae, Simkaniaceae and Waddliaceae. Based on the methodology of Everett et al. (1999), all members of the family Chlamydiaceae have 16S rRNA genetic sequences with $90 \%$ or greater identity. Chlamydia-like bacteria, or the 'environmental chlamydiae', are defined as possessing chlamydial life stages, e.g. reticulate bodies (RBs) and elementary bodies (EBs), and having 80 to $90 \%$ 16S rRNA gene sequence identity with members of the family Chlamydiaceae. Environmental chlamydiae have been shown to have an extremely diverse host range, and several have been associated with morbidity and mortality in humans and animals (Amann et al. 1997, Everett et al. 1999, Fritsche et al. 2000, Horn et al. 2000, Horn \& Wagner 2001, Deveraux et al. 2003, Draghi et al. 2004, Collingro et al. 2005, Corsaro \& Greub 2006). Although the agents of epitheliocystis in charr and other piscine hosts have yet to be successfully cultured in vitro, Draghi et al. (2004) and Meijer et al. (2006) have successfully characterized several intracellular bacteria associated with epitheliocystis in piscine hosts by applying molecular techniques directly to infected gill tissue in lieu of culture.

In 1998, an outbreak of respiratory disease with associated mortality occurred in Labrador strain (Fraser River) Arctic charr cultured at The Conservation Fund's Freshwater Institute. This outbreak was due to gill infection by a gram-negative intracellular bacterium (Noble et al. 1999). Between November of 1999 and June of 2002, 5 cohorts of specific-pathogenfree Arctic charr eggs were hatched and grown in the Freshwater Institute's commercial-scale, recirculating, research production system, which is located in a different watershed (but possibly connected by underlying karst geology) than that that housed the fish in the 1998 outbreak (Noble et al. 1999). Four of 5 cohorts experienced outbreaks of respiratory disease with the same clinical signs as in 1998 and histopathology consistent with epitheliocystis. As with the 1998 outbreak, the gill was the only affected organ. In addition to the Fraser River charr, Nauyuk Lake and Tree Rivers/ Nauyuk Lake hybrids also were affected. The purpose of the present study was to describe the histopathology, ultrastructure, partial 16S rRNA genetic sequence, and phylogenetic relatedness of the intracellular bacterium associated with an outbreak of epitheliocystis gill disease in Arctic charr from the spring of 2002 at the Freshwater Institute. Results of this study expand our knowledge of the diversity of clinically relevant environmental chlamydiae and may shed light on host ranges of these potential emerging pathogens.

\section{MATERIALS AND METHODS}

Fish. In the spring of 2002, 20 Arctic charr were sampled from the Freshwater Institute's recirculating, research production system during an outbreak of epitheliocystis. Fish were selected based on the presence of clinical signs of gill disease considered representative of the population and consistent with respiratory compromise. Fish were euthanized by immersion in $150 \mathrm{mg} \mathrm{l}^{-1}$ tricaine methane sulfonate (MS-222, Argent Chemical Laboratories). Gills were collected, fixed in $10 \%$ formalin and submitted to the Connecticut Veterinary Medical Diagnostic Laboratory (University of Connecticut, Storrs, CT, USA).

Histopathology. Twenty formalin-fixed gill samples were trimmed to fit plastic cassettes, processed routinely for paraffin embedding, sectioned at $4 \mu \mathrm{m}$, mounted on glass slides, and stained with hematoxylin and eosin (H\&E) according to standard histologic 
techniques (Sheehan \& Hrapchak 1980). Tissue sections were examined by light microscopy to identify histopathologic lesions and inclusions of epitheliocystis based on previous descriptions (Nylund et al. 1998, Noble et al. 1999, Draghi et al. 2004, Corsaro \& Greub 2006). Additional sections from blocks with evidence of epitheliocystis inclusions were stained using the Macchiavello (Pinkerton's), Lendrum's phloxinetartrazine and Gimenez (PVK modification) techniques (Gimenez 1964, Culling 1974).

Transmission electron microscopy (TEM) and immunogold labeling. For conventional TEM, formalinfixed gill tissues that had not been processed for paraffin embedment were trimmed to approximately $2 \times$ $3 \mathrm{~mm}$ and $1 \mathrm{~mm}$ thick, and were further fixed in a mixture of $1.25 \%$ formaldehyde, $2.5 \%$ glutaraldehyde, $0.03 \% \mathrm{CaCl}_{2}$ and $0.03 \%$ trinitrophenol in $0.05 \mathrm{M}$ cacodylate buffer pH 7.3 (Ito \& Rikihsa 1981), then post-fixed in $1 \% \mathrm{OsO}_{4}$ in $0.1 \mathrm{M}$ cacodylate buffer, stained en bloc with $1 \%$ uranyl acetate in $0.1 \mathrm{M}$ maleate buffer, dehydrated in ethanol and embedded in Poly/Bed 812 (Polysciences). To provide another option, formalin-fixed gill tissues were also fixed for TEM in equal parts of $8 \%$ glutaraldehyde and buffer to make a $4 \%$ glutaraldehyde solution. The buffer solution contained $8.3 \mathrm{ml}$ of $2.26 \%$ monosodium phosphate, $1.7 \mathrm{ml}$ of $2.52 \%$ sodium hydroxide, and $50 \mu \mathrm{l}$ of $1 \%$ calcium chloride. Tissue was fixed, then rinsed 3 times in cold $\left(4^{\circ} \mathrm{C}\right)$ glutaraldehyde. Fixed tissues were embedded in Spurr's resin, sectioned, placed onto copper uncoated grids and examined using a Philips 410 LS electron microscope.

For immunogold electron microscopy, trimmed samples were fixed in a mixture of $3 \%$ formaldehyde and $1 \%$ glutaraldehyde in $0.1 \mathrm{M}$ cacodylate buffer $\mathrm{pH} 7.2$ (McDowell \& Trump 1976), stained en bloc with $1 \%$ uranyl acetate in $0.1 \mathrm{M}$ maleate buffer, dehydrated in a graded series of ethanol, and embedded in LR White (SPI Supplies). Ultrathin sections were cut using a Reichert-Leica Ultracut S ultramicrotome (Leica Microsystems) and placed onto nickel Formvar-carboncoated grids. Grids were treated with blocking buffer ( $0.1 \%$ bovine serum albumin [BSA], $0.01 \mathrm{M}$ glycine in $0.05 \mathrm{M}$ Tris-buffered saline [TBS]) for $15 \mathrm{~min}$ at room temperature, incubated in a wet chamber (floating on the drops) with primary antibody for $1 \mathrm{~h}$ at room temperature, then overnight at $4^{\circ} \mathrm{C}_{i}$ grids were then washed in blocking buffer and incubated with secondary colloidal gold-labeled antibody for $1 \mathrm{~h}$ at room temperature. The primary antibody was commercial mouse anti-chlamydial LPS monoclonal antibody (Chemicon International) diluted 1:100 in diluting buffer $(0.05 \mathrm{M}$ TBS containing $1 \%$ BSA). The secondary antibody was goat anti-mouse immunglobulin IgG+IgM $(\mathrm{H}+\mathrm{L})$ labeled with $10 \mathrm{~nm}$ colloidal gold
(AuroProbe EM GAMIgG+IgM G10, RPN 431, Amersham Biosciences) diluted 1:20 in diluting buffer. Control grids were incubated in the same way as test grids except that primary antibody was omitted and replaced with diluting buffer. Grids were stained with uranyl acetate and lead citrate, then examined in a Philips 201 or Philips CM-100 electron microscope at $60 \mathrm{kV}$.

DNA extraction, amplification and cloning. Genomic DNA was extracted from fresh gill samples from each of the 20 Arctic charr using the Qiagen DNeasy extraction system (Qiagen) according to the mouse tail protocol of the manufacturer, with few modifications. Briefly, during lysis, gill tissues in tissue lysis buffer (ATL buffer; Qiagen) were heated to $97-100^{\circ} \mathrm{C}$ for $15 \mathrm{~min}$ to assist in release of prokaryotic nucleic acids. Tissue lysis solutions were then cooled to $55^{\circ} \mathrm{C}$, Proteinase $\mathrm{K}$ was added, and lysates were incubated at $55^{\circ} \mathrm{C}$ overnight. Column binding, washing, and elution of DNA were performed according to manufacturer's instructions, and eluates were assessed for purity and quantity by either spectrophotometry at 260 and $280 \mathrm{~nm}$ or fluorometry (Bio-Rad VersaFluor Fluorometer). DNA extractions were then aliquoted and stored at $4{ }^{\circ} \mathrm{C}$ for immediate use or frozen at $-80^{\circ} \mathrm{C}$ for future experiments. Negative control genomic charr DNA was extracted from whole blood samples of clinically unaffected charr; positive control genomic chlamydial DNA was extracted from a culture of Chlamydia trachomatis (ATCC \#VR1477, American Type Culture Collection). Nucleic acid extracted from charr gills was tested for its ability to support amplification-based experiments by PCR amplification of host 18S rDNA using primers $18 \mathrm{e}$ and $18 \mathrm{i}$ (to yield a $440 \mathrm{bp}$ product) or $18 \mathrm{e}$ and $18 \mathrm{~g}$ (to yield a $1.8 \mathrm{~kb}$ product) (Hillis \& Dixon 1991) as described previously (Draghi et al. 2004).

Oligonucleotide primers to conserved sites along the 16S rRNA gene among members of the order Chlamydiales were used to amplify a $16 \mathrm{~S}$ rDNA signature sequence of approximately 300 bp (Everett et al. 1999). Primers for all PCR experiments were synthesized by Invitrogen, and rehydrated to a stock concentration

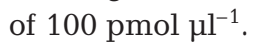

All 16S rDNA PCR products were amplified in individual $50 \mu \mathrm{l}$ reaction mixtures containing 100 to $150 \mathrm{ng}$ of sample DNA, $5 \mu \mathrm{l} 10 \times$ Qiagen buffer $(100 \mathrm{mM}$ TrisHCL, pH 8.3, $500 \mathrm{mM} \mathrm{KCl}, 15 \mathrm{mM} \mathrm{MgCl}_{2}, 0.01 \%$ gelatin), $200 \mathrm{mM}$ dNTPs, $20 \mathrm{pmol} \mu^{-1}$ each primer, and $1 \mathrm{U}$ Qiagen HotStar Taq polymerase (Qiagen) using Perkin-Elmer Model 2400 thermal cyclers (Applied Biosystems). Because a predicted degree of identity was expected between the target and primers, but the exact percent identity was unknown, a touchdown PCR protocol (Palumbi 1996) was used to limit secondary priming and the creation of spurious products. Reactions were as follows: $15 \mathrm{~min}$ incubation 
at $95^{\circ} \mathrm{C}$, followed by $30 \mathrm{~s}$ at $94^{\circ} \mathrm{C}, 45 \mathrm{~s}$ at $66^{\circ} \mathrm{C}$, and $30 \mathrm{~s}$ at $72^{\circ} \mathrm{C}$. Annealing temperatures were decreased by $1^{\circ} \mathrm{C}$ every third cycle until $61^{\circ} \mathrm{C}$. Annealing times at 65,64 , and $63^{\circ} \mathrm{C}$ were $30 \mathrm{~s}$, while annealing times at 62 and $61^{\circ} \mathrm{C}$ were $15 \mathrm{~s} ; 25$ cycles were performed at the final annealing temperature of $61^{\circ} \mathrm{C}$. After a total of 40 cycles, a 7 min final extension step at $72^{\circ} \mathrm{C}$ was performed. Products were separated by electrophoresis in $2 \%$ agarose gels and visualized by ethidium bromide staining and UV transillumination. Images were recorded digitally using a Stratagene Eagle Eye II-still video image capture system (Stratagene). Reactions that yielded amplicons of the correct molecular size were repeated; samples that amplified twice were considered positive for chlamydia-like bacteria (CLB) and used for further analysis. Initial 16S rDNA PCR products were either excised and purified from agarose gels or were purified directly from amplification reactions (Qiagen mini-elute gel extraction kit or PCR purification kit). Purified $16 \mathrm{~S}$ signature sequence PCR products were submitted for direct sequencing to determine template homogeneity, whereas signature sequence products for riboprobe generation were cloned into a dual-promoter transcription vector $(\mathrm{pCR}$ II TOPO TA vector: Invitrogen) and screened by PCR; plasmid DNA was purified using the Qiagen miniprep DNA purification kit and sequenced using M13 priming sites.

DNA sequencing and analysis. Nucleotide sequences of both directly sequenced and cloned PCR products were determined by assembling ABI (Applied Biosystems) sequence files of sense and antisense strands using Sequencher for Macintosh Version 4.5 (Gene Codes). Consensus sequences were generated from 5 individual gill samples from 5 different fish using the multiple sequence alignment algorithm of Sequencher for Macintosh. Base discrepancies were resolved by simple majority rulings. Standard nucleotide-nucleotide sequence comparisons were made by conducting BLAST-n (Altschul et al. 1990, 1997) searches of the National Center for Biotechnology Information databases (www.ncbi.nlm.nih.gov).

Molecular phylogenetic analyses. The consensus 16S rRNA gene signature sequence was aligned with 16S signature sequences of other chlamydiae and $16 \mathrm{~S}$ rRNA genetic sequences from relevant, related, intracellular, gram-negative taxa according to prior molecular systematic studies of members of the order Chlamydiales (Everett et al. 1999), Neochlamydia hartmannellae (Horn et al. 2000) and endosymbionts of Acanthamoeba spp. (Fritsche et al. 2000), and members of the order Rickettsiaceae (Dumler et al. 2001). These included sequences from Chlamydophila abortus EBA (U76710), C. psittaci MN (AB001784), C. psittaci NJ1 (U68419), C. caviae GPIC (D85708), C. felis FP Cello (D85706), C. pneumoniae N16 (U68426), C. pneumoniae TW-183 (U76711), C. pecorum E58 (D88317), C. pecorum IPA (D85716), C. trachomatis A/Har-13 (D89067), C. trachomatis B/TW-5/OT (D85719), Chlamydia trachomatis D/UW-3/CX (D85721), C. trachomatis L2/434/BU (U68443), C. suis S45 (U73110), C. suis R22 (U68420), C. muridarum MoPn (85718), C. muridarum SFPD (U68437), Waddlia chondrophila (AF042496), Neochlamydia hartmannellae (AF177275), Parachlamydia acanthamoebae $\mathrm{Bn}_{\mathrm{g}}$ (Y07556), Simkania negevensis Z (L27666), endosymbiont of Acanthamoeba sp. UWC22 (AF083616), endosymbiont of Acanthamoeba sp. UWE1 (AF083614), Rickettsia sp. (AY158006), Neorickettsia helminthoeca (U12457), R. rickettsii Strain R (L36217), R. typhi Wilmington (U12463), Ehrlichia chaffeensis (M73222), E. chaffeensis (U86664), E. risticii (M21290), E. sennetsu (M73225), Rickettsia sp. (Ixodes scapularis symbiont) (D84558), Orientia tsutsugamushi strain Gilliam (D38622), Ehrlichia sp. 'HGE agent' (U02521), Ehrlichia sp. 'HGE agent' (isolate CAHU-HGE1) (AF093788), Ehrlichia sp. (AB074460), candidatus Piscichlamydia salmonis (AY462244) and the agent of withering syndrome in abalone (AF069062). Sequences were aligned, edited by visual inspection, and formatted using CLUSTAL X v1.81 (ftp://ftp-igbmc.u-strasbg. fr/pub/ClustalX/) (Thompson et al. 1997). Phylogenetic analyses using distance and parsimony were conducted using PAUP* v4.0b10 for Macintosh (Swofford 2000). Parsimony analyses were conducted using heuristic search settings that included random starting trees, 100 random addition sequence replicates, treebisection-reconnection branch swapping, and collapsing of branches to create polytomies if maximum branch lengths were zero. Distance-based analyses employed the HKY85 2-parameter model and neighbor-joining to obtain starting trees. In heuristic parsimony searches the number of parsimony-informative characters was 187. Estimates of confidence at nodes were obtained through 1000 bootstrap replicates of heuristic searches (Felsenstein 1985).

In situ hybridization using riboprobes. In situ hybridization (ISH) was conducted utilizing riboprobes generated by in vitro transcription of cloned 16S rDNA amplicons, as previously described (Brown 1998, Draghi et al. 2004) by employing a dual-promoter vector (pCRII TOPO vector: Invitrogen). Inserts were confirmed and orientations determined by DNA sequencing. Plasmids were linearized by restriction enzyme digestion and confirmed by gel electrophoresis. Linearized plasmids were precipitated in $100 \%$ ethanol with sodium acetate and EDTA at $-80^{\circ} \mathrm{C}$, washed in $70 \%$ cold ethanol, air-dried, rehydrated in diethyl pyrocarbonate (DEPC)-treated, autoclaved, double-distilled, Millipore-filtered water (Simplicity 185: Millipore Cor- 
poration). Riboprobes of the $\sim 300$ bp $16 \mathrm{~S}$ rRNA genetic sequence from infected Arctic charr gills were generated by in vitro transcription using the Sp6/T7 DIG RNA labeling kit (Roche Applied Science) or the AmpliScribe T7 or Sp6 High Yield transcription kits (Epicentre Biotechnologies) in combination with 10X digoxigenin-labeled nucleotide mix (Roche Applied Science). Sp6 and T7 RNA polymerases were used in separate labeling reactions according to manufacturers' instructions. To serve as a nonhomologous probe control, the cloned 16S rRNA gene of Mycoplasma gallisepticum was transcribed in vitro in identical fashion. Transcribed riboprobes were precipitated in ethanol, resuspended in DEPC-treated water, and assessed by dot blot analysis for probe concentrations.

Riboprobes were used in nonisotopic in situ hybridization experiments based on procedures previously described (Gan et al. 1994, Brown, 1998, Draghi et al. 2004). H\&E-stained tissue sections of gill were examined by light microscopy for the number and distribution of epitheliocystis inclusions, and serial tissue sections at $4 \mu \mathrm{m}$ were mounted unstained on ProbeOn Plus glass slides (Fisher Scientific). Unstained tissue sections were heated to $70^{\circ} \mathrm{C}$ for $10 \mathrm{~min}$, deparaffinized in three $3 \mathrm{~min}$ washes of xylene (Sigma), and rehydrated in $1 \times$ PBS with $5 \mathrm{mM}$ $\mathrm{MgCl}$ for $15 \mathrm{~min}$ at room temperature. Sections were digested with $20 \mathrm{ng} \mathrm{ml}^{-1}$ Proteinase $\mathrm{K}$ at $37^{\circ} \mathrm{C}$ for $15 \mathrm{~min}$, covered with pre-hybridization solution [ $5 \times$ sodium chloride, sodium citrate, $5 \%$ blocking reagent, $49 \%$ formamide, $0.02 \%$ SDS, $0.1 \%$ N-laurolysarcosine] for $1.5 \mathrm{~h}$ at $40^{\circ} \mathrm{C}$. Slides were heated to $95^{\circ} \mathrm{C}$ for $5 \mathrm{~min}$ to denature target DNA, then sections were covered with $100 \mu \mathrm{l}$ of hybridization solution (a total of $100 \mathrm{ng}$ digoxigeninlabeled riboprobe [sense and antisense probes] $100 \mathrm{l}^{-1}$ prehybridization solution) per slide, coverslipped, and allowed to hybridize overnight at $42{ }^{\circ} \mathrm{C}$ in a humidified Bokel slide moat (Fisher Scientific). After hybridization, slides were washed in $2 \times \mathrm{SSC}$ with $1 \% \mathrm{SDS}$ at $40^{\circ} \mathrm{C}$ for $20 \mathrm{~min}$, followed by $1 \times \mathrm{SSC}$ with $0.1 \% \mathrm{SDS}$ at $40^{\circ} \mathrm{C}$ for $20 \mathrm{~min}$, then $1 \times \mathrm{SSC}$ for $10 \mathrm{~min}$ at room temperature and $0.1 \times \mathrm{SSC}$ for $10 \mathrm{~min}$ at room temperature. Slides were washed in Buffer I (0.1 M Tris pH 7.5, 0.15 M NaCl) for $10 \mathrm{~min}$, then sections were incubated for $2 \mathrm{~h}$ at $37^{\circ} \mathrm{C}$ in a humidified chamber with 100 to $200 \mu \mathrm{l}$ Buffer I containing $2 \%$ sheep serum and anti-digoxigenin Fab fragments conjugated to alkaline phosphatase (Roche Applied Science) at 1:250 dilution. Slides were washed for $10 \mathrm{~min}$ in Buffer I, then washed twice in TBST $(0.15 \mathrm{M}$ $\mathrm{NaCl}, 2.7 \mathrm{mM} \mathrm{KCl}, 25 \mathrm{mM}$ Tris, $0.05 \%$ Tween 20, pH 7.6) for 5 min each. Hybridization signal was developed using the DAKO Permanent Red-Substrate System (Dako Cytomation) with levamasole (Sigma); slides were counterstained with 1/10th Gill's modified hematoxylin, air dried for $1 \mathrm{~h}$ and coverslipped according to the instructions of the manufacturer (Dako Cytomation).

\section{RESULTS}

\section{Clinical findings}

During the 4 outbreaks that occurred between 1999 and 2002, clinical signs began with the gradual onset of generalized population lethargy and decreased feed
Fig. 1. Salvelinus alpinus. Proliferative gill lesions in Arctic charr with epitheliocystis. There is basal to complete interlamellar filling by hyperplastic epithelium with foci of bridging of epithelium across the tips of consecutive lamellae and intraepithelial eosinophilic granular cells; an epitheliocystis inclusion (arrow) is present in the hyperplastic epithelium. H\&E. Scale bar $=100 \mu \mathrm{m}$

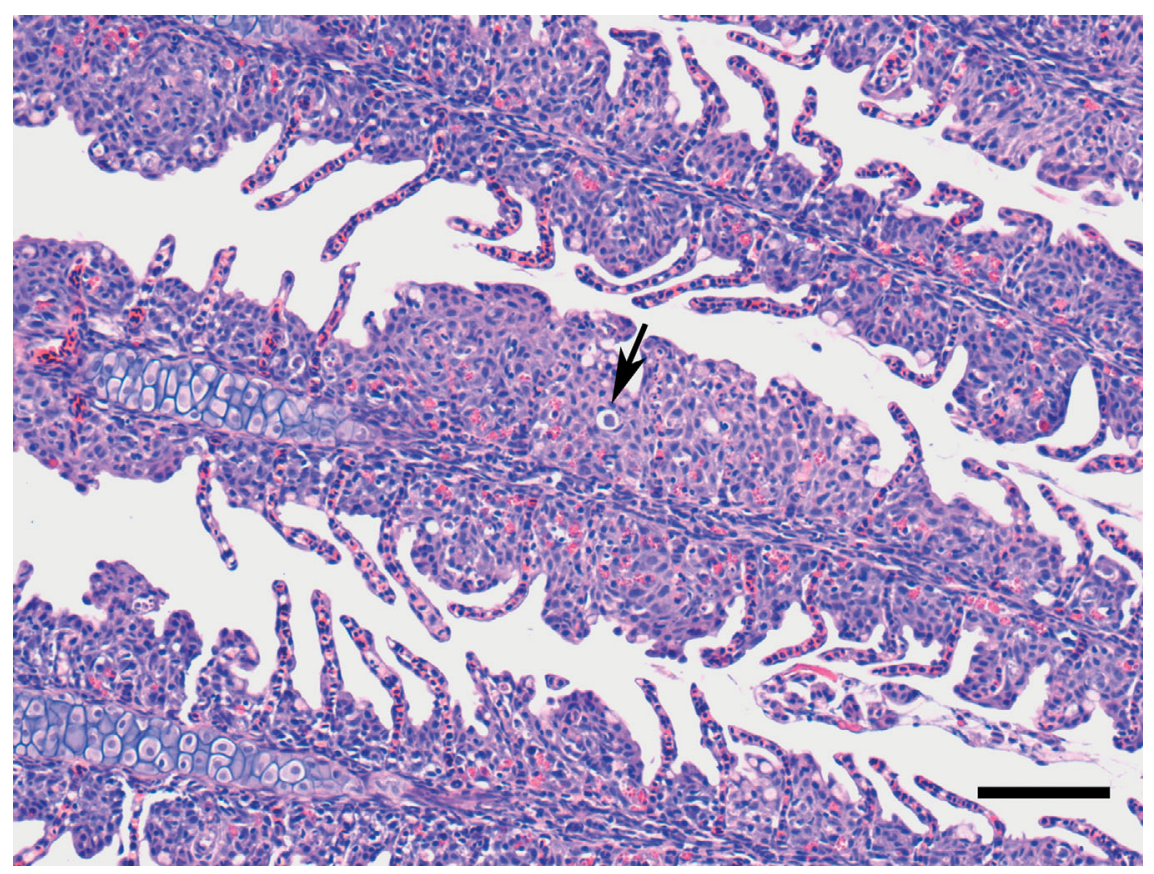


consumption, and progressed to complete anorexia. Fish swam near the water surface with or without exposing their dorsal fin, had flared operculae, and some gasped at the water surface. Cumulative percent mortality ranged from 18 to $44 \%$, with an average of $31 \%$.

\section{Histopathology}

All 20 clinically diseased Arctic charr had proliferative gill lesions and bacterial inclusions consistent with epitheliocystis. Gill lesions consisted of diffuse, basal to complete, interlamellar filling by hyperplastic epithelium with foci of epithelial bridging and occasional lamellar fusion; infiltrates of lymphocytes and histiocytes in the stroma of filaments and intraepithelial eosinophilic granular cells accompanied the lamellar epithelial hyperplasia (Fig. 1). Congestion, hemorrhage, lamellar aneurysms or thrombi were infrequent. Bacterial inclusions were represented by sharply marginated vacuoles that expanded the cytoplasm of epithelial cells, often pushing the nucleus to the periphery of the cell, and contained dense granular cores which were surrounded by clear space haloes and were basophilic in H\&E-stained tissue sections (Fig. 2A). Inclusions were differentially stained by several special staining techniques that have traditionally been used to stain chlamydia in tissue sections, e.g. Macchiavello (Fig. 2B) and Gimenez (Fig. 2C), as well as by a stain typically used to highlight DNA inclusion bodies, Lendrum's phloxine-tartrazine (Fig. 2D).
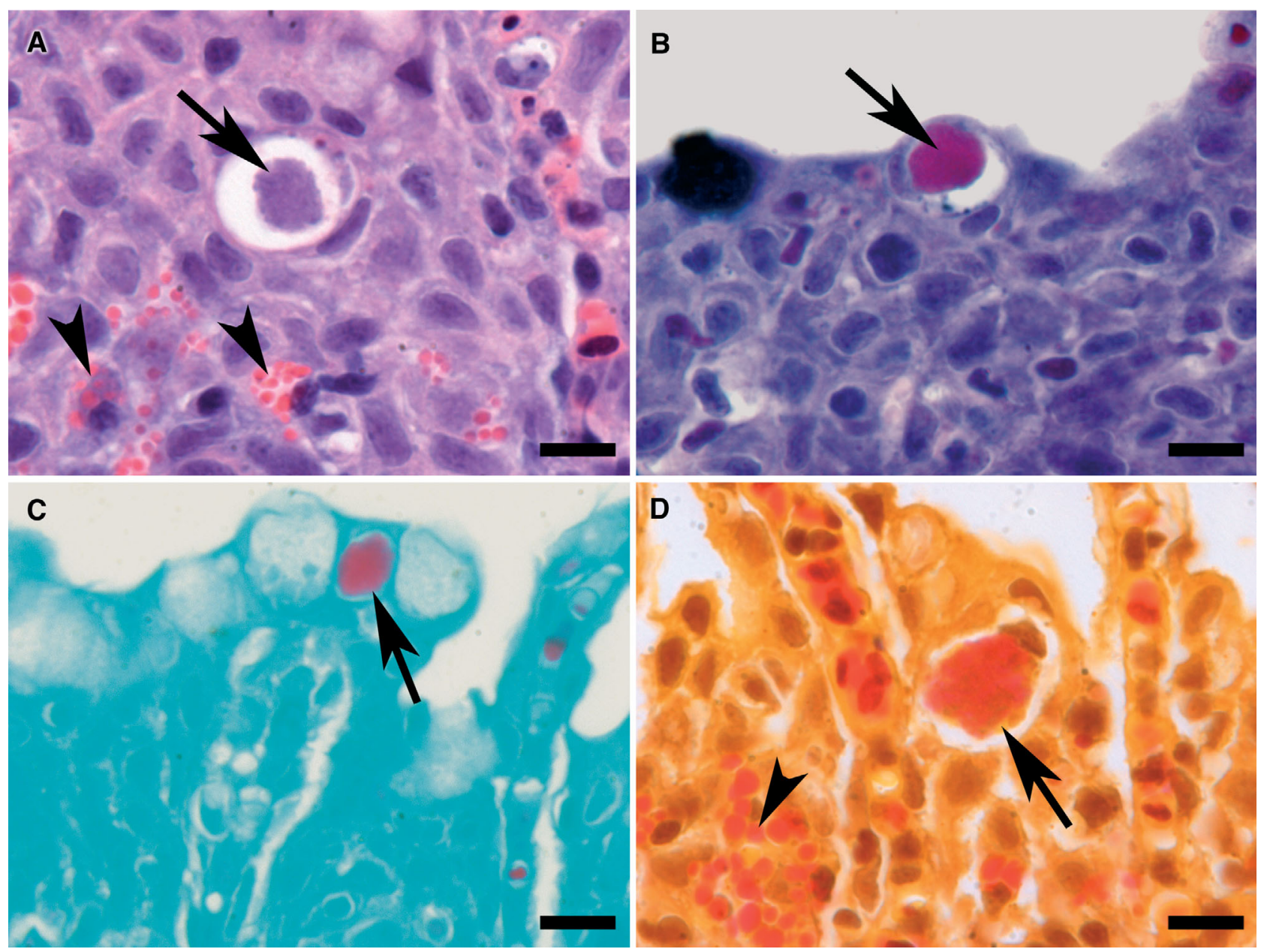

Fig. 2. Salvelinus alpinus. Neochlamydial inclusions in proliferative gill lesions of Arctic charr highlighted by various special stains. Inclusions (arrows) are represented by sharply marginated vacuoles within the cytoplasm of epithelial cells that contain dense granular cores which are (A) basophilic in H\&E, (B) fuchsinophilic when stained by the Macchiavello technique, (C) brick red when stained by the Gimenez technique, and (D) red when stained by the Lendrum's phloxine-tartrazine technique. Cytoplasmic granules of eosinophilic granular cells (arrowheads) are (A) brightly eosinophilic when stained by the H\&E technique and (D) red in Lendrum's, but are not differentially stained by the (B) Macchiavello and (C) Gimenez techniques (not shown). Scale bars $=10 \mu \mathrm{m}$ 

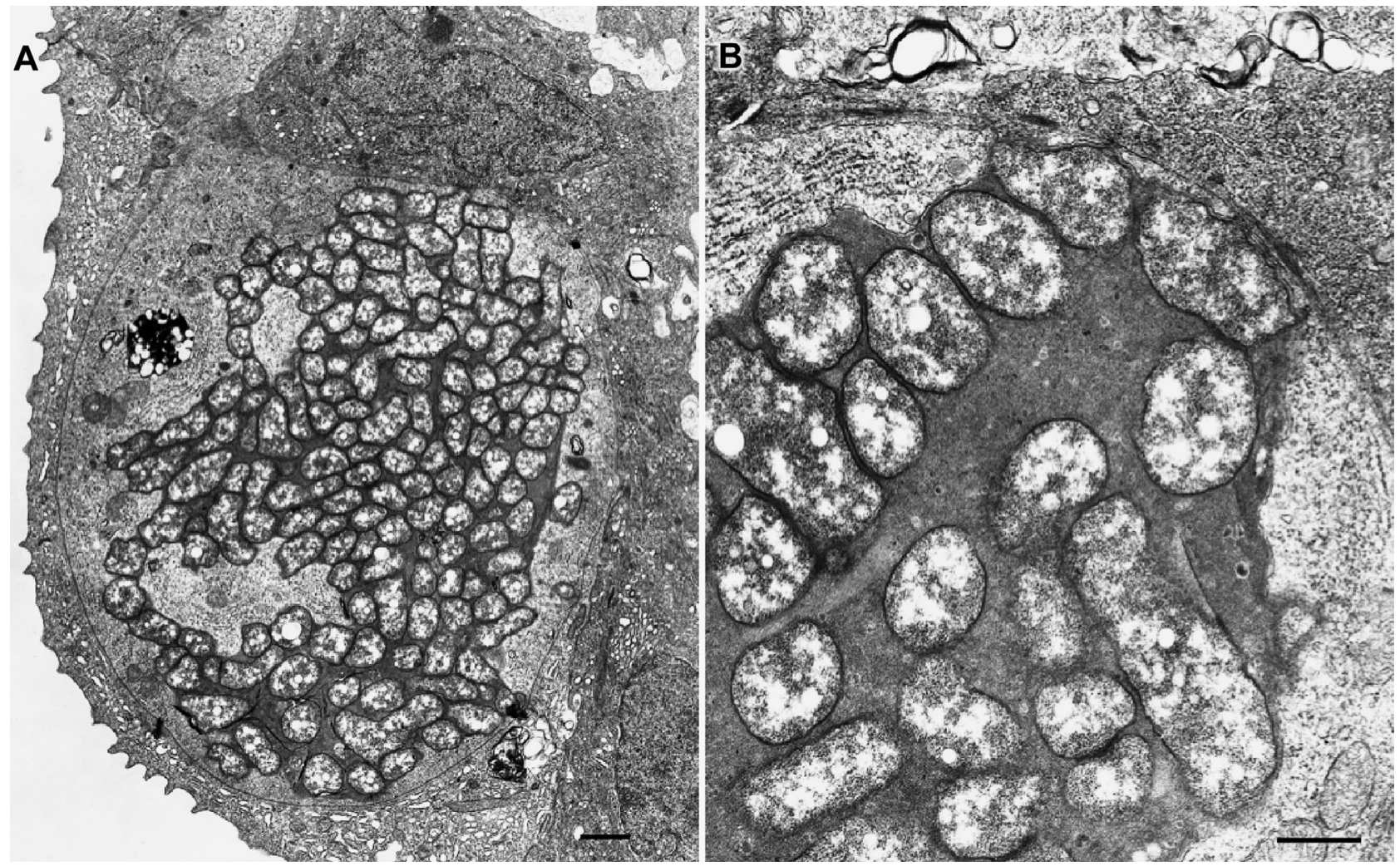

Fig. 3. Salvelinus alpinus. Transmission electron photomicrographs of neochlamydia inclusion in branchial epithelium of Arctic charr. (A) Inclusion is located in the cytoplasm, is irregularly shaped with several projections and indentations, and is entirely membrane-bound, containing round to ovoid reticulate bodies of varying sizes embedded in an osmiophilic matrix. Scale bar $=$ $1 \mu \mathrm{m}$. (B) Higher magnification reveals that reticulate bodies are surrounded by distinct membranes, have dispersed granular cytoplasmic contents, and are separated by an amorphous, fibrillar matrix of moderate electron density. Scale bar $=0.5 \mu \mathrm{m}$

\section{Electron microscopy}

Transmission electron photomicrographs revealed inclusions to be membrane-bound vacuoles in the cytoplasm of branchial epithelial cells and that these vacuoles contained reticulate bodies, which were variably sized, round to oval or elongate (Fig. 3A). EBs were not seen. The size of RBs ranged from $0.5-0.7$ to $1.1-1.3 \mu \mathrm{m}$ with some up to $2.5 \mu \mathrm{m}$. They possessed 2 tightly apposed membranes, i.e. an inner cytoplasmic membrane and an outer cell wall membrane, with no visible periplasmic space between (Fig. 3B). An amorphous, osmiophilic, fibrillar matrix surrounded RBs within vacuoles (Fig. 3B). No inclusions were identified in cells other than epithelial cells.

\section{Immunogold electron microscopy}

Staining with a mouse monoclonal anti-chlamydial lipopolysaccaride antibody resulted in mild to moder- ate labeling of membranes and cytoplasm of RBs in inclusions. No labeling was apparent when the goat anti-mouse secondary antibody was used alone in staining reactions (Fig. 4).

\section{DNA sequencing and analysis}

Of the 20 charr tested using the touch-down PCR protocol targeted to the signature sequence of the $16 \mathrm{~S}$ rRNA gene of the Chlamydiales (Everett et al. 1999), 5 fish amplified twice in separate PCR experiments. The resultant PCR products were sequenced directly, and 5 products from a third PCR from the same 5 fish were cloned for both sequencing and riboprobe transcription. A consensus sequence was generated from all PCR products. BLAST-n analysis revealed that PCR products had greater than $97 \%$ identity with uncultured clinical Neochlamydia sp. AY225594.1. Cloned fragments were $100 \%$ identical to the $16 \mathrm{~S}$ signature sequence of uncultured clinical Neochlamydia sp. AY225593.1. 

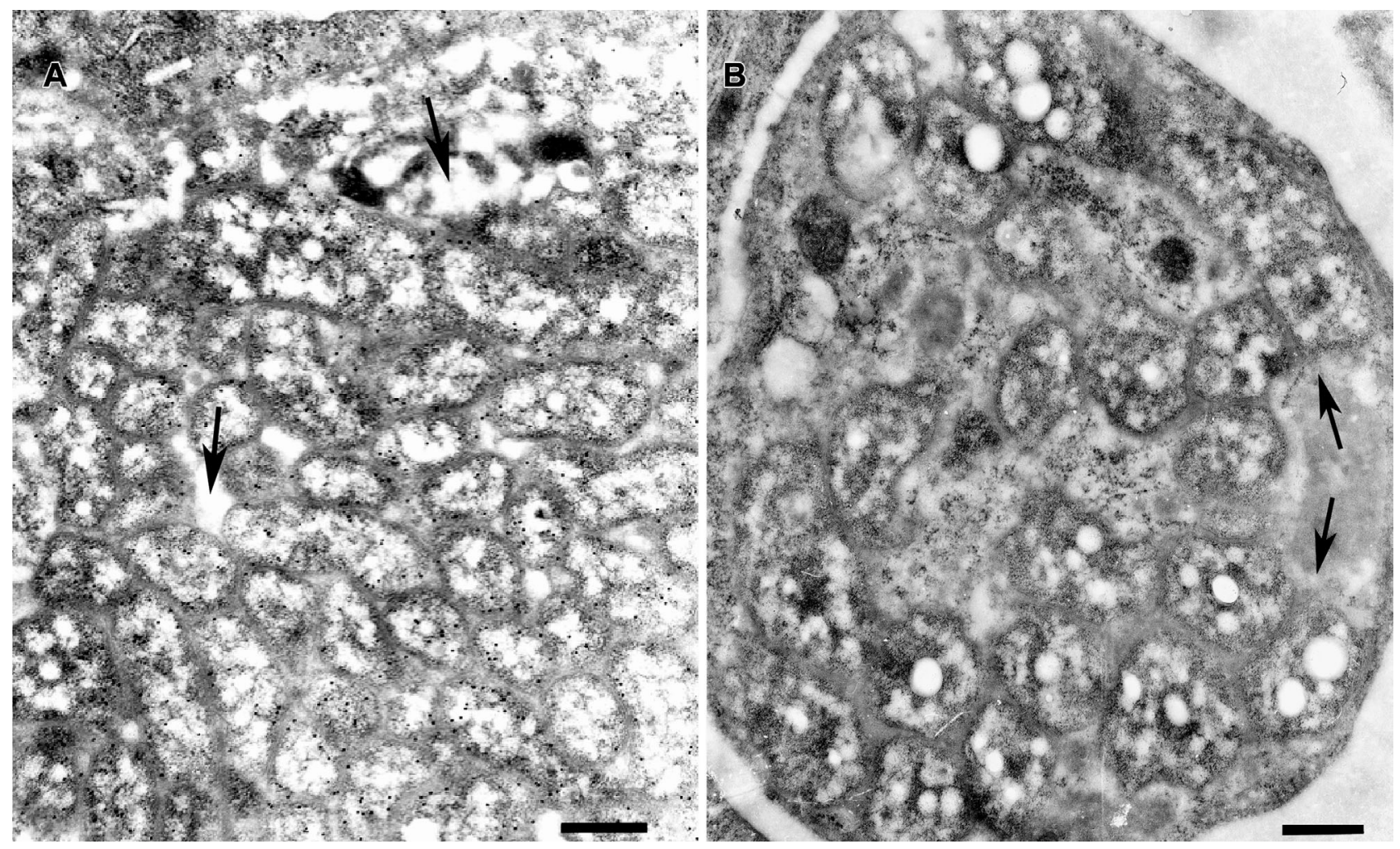

Fig. 4. Salvelinus alpinus. (A) Immunogold staining using anti-chlamydial LPS antibody results in labeling of outer membranes and cytoplasm of reticulate bodies. Note absence of labeling from spaces between and adjacent to reticulate bodies (arrows). (B) No labeling of cytoplasm and membranes (arrows) of reticulate bodies is apparent when secondary antibody alone is applied. Scale bars $=0.5 \mu \mathrm{m}$

\section{Molecular phylogenetic analyses}

A bootstrap consensus phylogram was generated by distance and parsimony algorithms that placed the $16 \mathrm{~S}$ signature sequence from charr with sequences of members of the Chlamydiales with high confidence (98 and $100 \%$ for distance and parsimony, respectively). The bacterium from charr branched with members of the outlying families of the order Chlamydiales, grouping as a sister taxon to Neochlamydia hartmannellae (family Parachlamydiaceae) in distance-based analyses (Fig. 5).

\section{In situ hybridization}

Serial sections were tested in triplicate in each experiment using (1) no probe, (2) $1.5 \mathrm{~kb}$ Mycoplasma gallisepticum $16 \mathrm{~S}$ riboprobe, and (3) the $300 \mathrm{bp}$ charr Neochlamydia sp. signature sequence-specific riboprobe. The 300 bp Neochlamydia sp. riboprobe demonstrated intense and specific labeling of the inclusions within branchial epithelial cells. Slides receiving no probe or the non-target riboprobe had no signal (Fig. 6).

\section{DISCUSSION}

Inclusions from charr gill lesions in this study were morphologically similar to those described in previous outbreaks of epitheliocystis in Arctic charr at the Freshwater Institute (Noble et al. 1999). In Arctic charr from 2002, inclusions were composed exclusively of RBs surrounded by a moderately electron-dense matrix. The membrane-bound nature of cytoplasmic inclusions surrounding RBs distinguishes the bacterium as chlamydia-like rather than rickettsia-like (Avakyan \& Popov 1984, Nylund et al. 1998, Crespo et al. 1999, Kahane et al. 1999, Dumler et al. 2001, Dumler \& Walker 2005). It is notable that some chlamydia-like bacteria that are endocytobionts of free-living amoebae, such as Neochlamydia hartmanellae, an endoparasite of the amoeba Hartmannella vermiformis, do not reside in membrane-bound vacuoles in the cytoplasm of their host amoeba (Horn et al. 2000).

Immunogold-labeling experiments provided evidence that the mouse monoclonal anti-chlamydial LPS antibody (Chemicon International) reacted with membranes and cytoplasm of epitheliocystis inclusions, indicating the presence of related trisaccharides. Inter- 


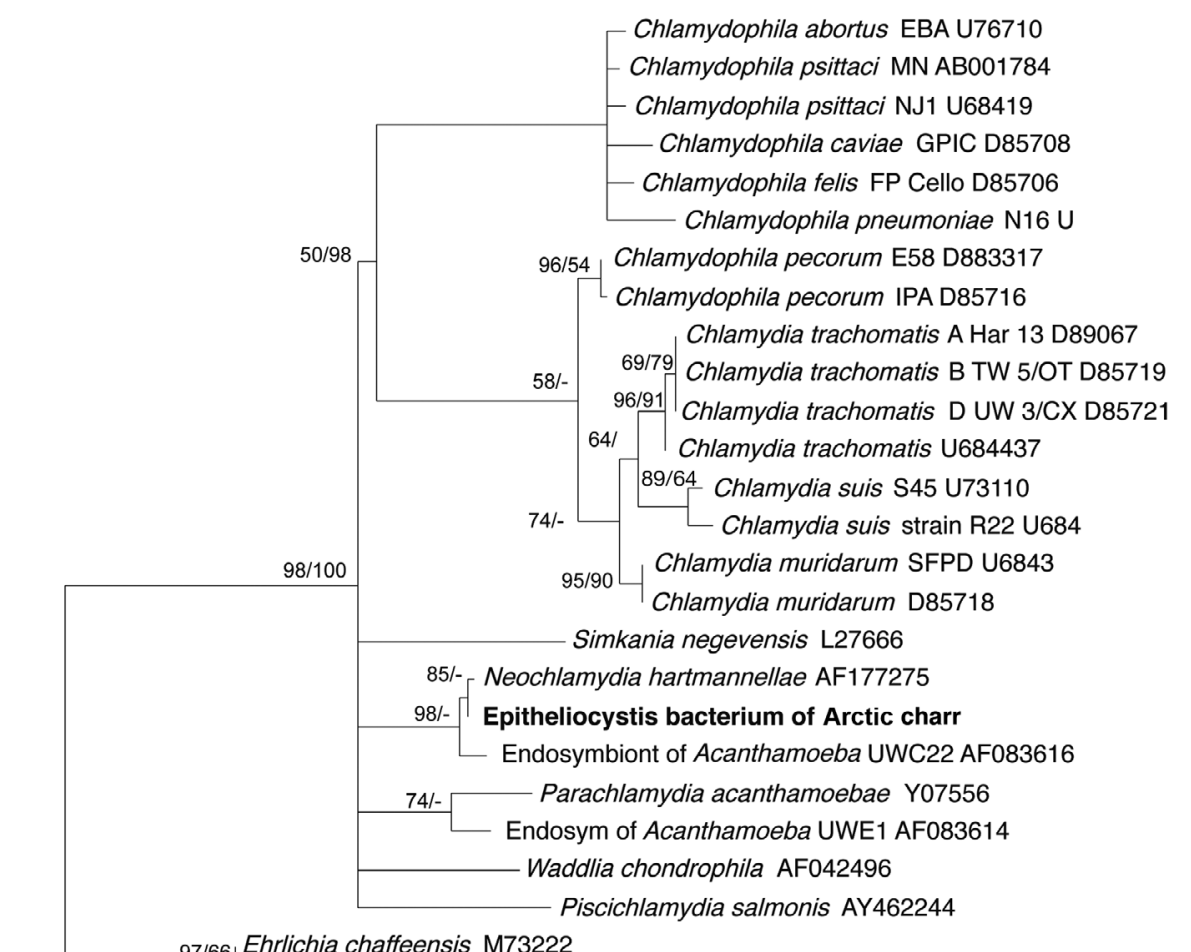

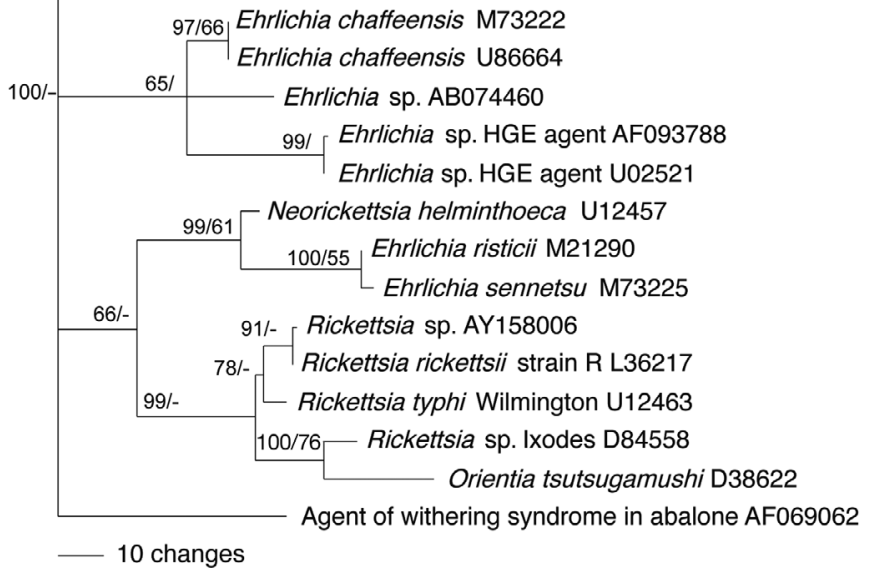

Fig. 5. Bootstrap consensus phylogram generated by distance and parsimony algorithms using 16S rRNA gene signature sequences of members of the order Chlamydiales and corresponding sequence regions of the 16S rRNA genes of members of the order Rickettsiales, including species of Ehrlichia. Bacterium associated with epitheliocystis inclusions in Arctic charr branched with members of the family Parachlamydiaceae, as a sister taxon to Neochlamydia hartmannellae. Bootstrap confidence values for distance and parsimony are listed as percentages of 1000 replicates. Outgroup was the agent of abalone withering syndrome pretations of these results must be made with great care. The antibody used in this study is thought to be specific for members of the family Chlamydiaceae; however, it did react with the intracellular bacterium identified in Arctic charr, suggesting the presence of similar epitopes to those of the family Chlamydiaceae. Current understanding is that members of the family Chlamydiaceae are recognized by antibodies that detect the LPS trisaccharide $\alpha$ Kdo- $(2 \rightarrow 8)$ - $\alpha$ Kdo- $(2 \rightarrow 4)$ $\alpha$ Kdo (Löbau et al. 1995). In an apparent contradiction, the 16S rRNA sequence data from the agent from charr place that bacterium within the family Parachlamydiaceae. Other studies have used anti-chlamydial LPS antibody in immunogold-labeling experiments and found labeling of chlamydia that were determined not to be affiliated with the family Chlamydiaceae (Draghi et al. 2004, Corsaro \& Greub
2006). However, no positive immunohistochemical staining of epitheliocystis inclusions was reported in a variety of fish species, including Arctic charr, using group-specific chlamydial antibody and the methods described in Groff et al. (1996), which employed the 11B5 antibody specific for the chlamydial genus-specific LPS antigen (Nowak \& LaPatra 2006). On the other hand, variability in the immunohistochemical staining results between epitheliocystis specimens from the same fish species has been reported, such that epitheliocystis infections in one fish species have given different immunohistochemical staining results based on the geographic sources of the samples or the antibody used or the labeling technique employed (Nowak \& LaPatra 2006). Further characterization of these macromolecules from environmental chlamydia is necessary to better understand their relative compositions 

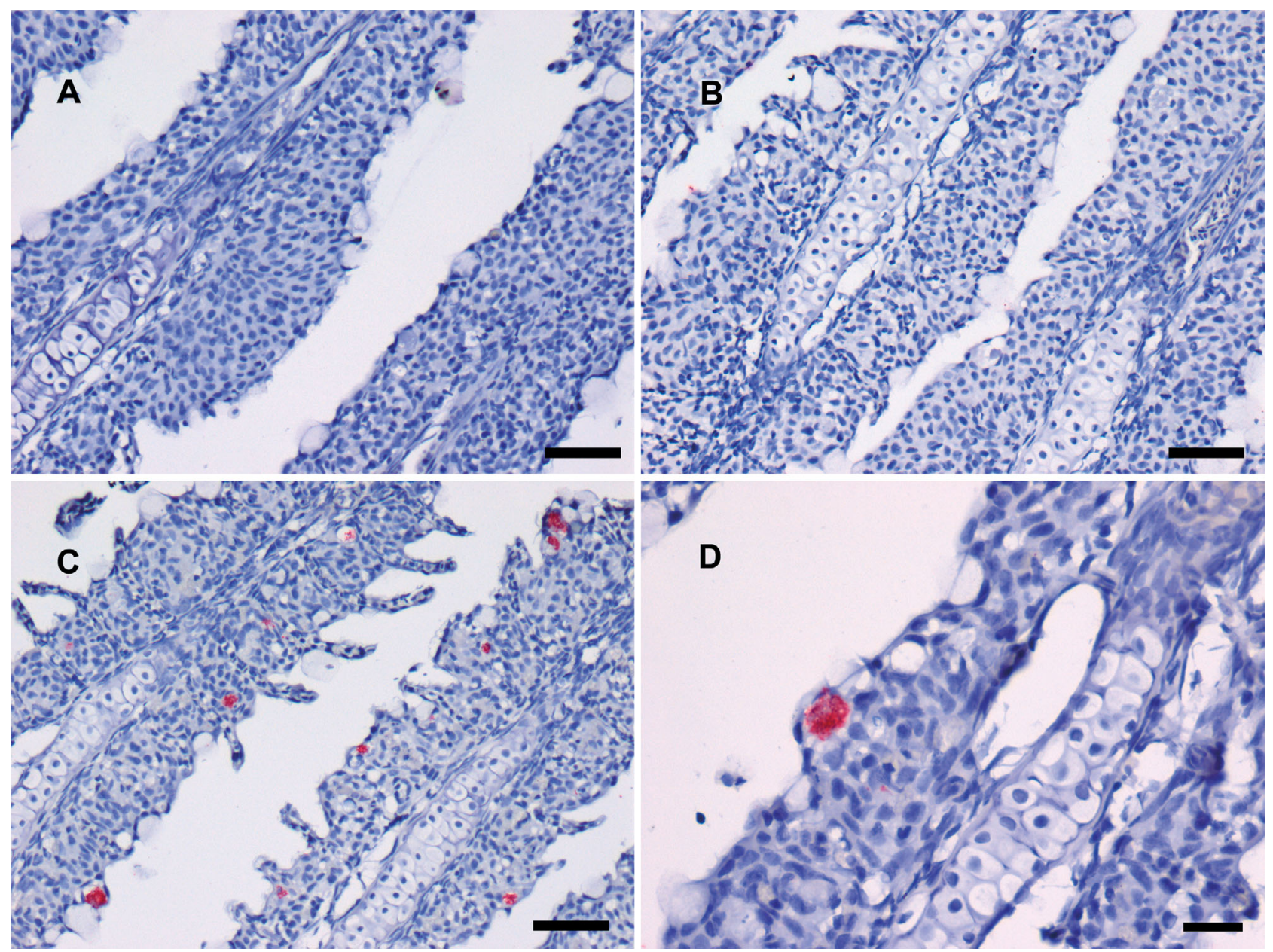

Fig. 6. Salvelinus alpinus. In situ hybridization performed on Arctic charr gill with epitheliocystis using a 300 bp digoxigeninlabeled riboprobe transcribed from the Neochlamydia sp. 16S rRNA signature sequence. No labeling detectable in sections that received (A) no riboprobe or (B) the Mycoplasma gallisepticum 16S rRNA riboprobe, which served as a nonhomologus riboprobe control. (C) Specific, granular, bright red labeling of bacterial inclusions is apparent in gill sections that received the Neochlamydia sp. 16S rRNA riboprobe. (D) Higher magnification of the hybridization reaction reveals that the signal development is restricted to the cytoplasm of the infected branchial epithelial cell. Scale bars $(A-C)=50 \mu \mathrm{m},(\mathrm{D})=20 \mu \mathrm{m}$

and to lend insight into their utility in describing the taxonomic range of chlamydiae involved in epitheliocystis.

The phylogram obtained in this study employed 16S signature sequences of chlamydiae and corresponding fragments of 16S rRNA gene sequences of rickettsiae, and resembled those of previous molecular phylogenetic analyses using full length, or near-full length, 16S rRNA gene sequences (Palys et al. 1997, Pettersson et al. 1997, Everett et al. 1999, Horn et al. 2000, Dumler et al. 2001, Draghi et al. 2004, Collingro et al. 2005). The $16 \mathrm{~S}$ sequence of this particular epitheliocystis-associated bacterium from charr branched with those of members of the outlying families of the order Chlamydiales as a sister taxon to Neochlamydia hartmannellae AF177275. Members of the outlying fami- lies of the order Chlamydiales, e.g. the Waddliaceae, Parachlamydiaceae, and the Simkaniaceae, have been termed 'environmental chlamydiae' or 'novel chlamydia' (Horn et al. 2000, Horn \& Wagner 2001, Corsaro \& Venditti 2004, Collingro et al. 2005, Corsaro \& Greub 2006), and N. hartmannellae has been shown to be an endocytobiont or endoparasite of the free-living amoeba Hartmannella vermiformis (Horn et al. 2000). It is possible, therefore, that the Neochlamydia sp. infecting Arctic charr gill may also exist in free-living amoebae such as Acanthamoeba spp. or Hartmannella spp., which suggests a possible environmental source or reservoir of infection and reaffirms previous notions that free-living amoebae may harbor the chlamydialike bacteria associated with epitheliocystis (Fritsche et al. 2000, Horn et al. 2000, Horn \& Wagner 2001, 
Draghi et al. 2004, Corsaro \& Greub 2006). The absence of native Arctic charr from the watershed and water source of the Freshwater Institute further supports this possibility. These data also reaffirm that several different bacteria of the order Chlamydiales are associated with epitheliocystis (Draghi et al. 2004, Corsaro \& Greub 2006, Meijer et al. 2006, Nowak \& LaPatra 2006).

Everett et al. (1999) proposed that direct sequencing of PCR products would allow rapid identification of members of the order Chlamydiales. The $300 \mathrm{bp}$ signature sequence from the $5^{\prime}$-end of the 16S rRNA gene is the most polymorphic and, hence, the most phylogenetically informative region of the ribosomal operon, such that amplification of this region allows phylogeny to be inferred with reasonable confidence (Engel \& Ganern 1987, Everett et al. 1999). Despite the fact that small fragments may not be ideal for phylogenetic inference (Corsaro \& Greub 2006), even smaller fragments from the 5 '-end of the 16S rRNA gene have been used to identify 'novel' chlamydiae and infer phylogeny (Meijer et al. 2006). The agents that share the highest nucleotide sequence identity with the $300 \mathrm{bp}$ 16S signature sequence of the bacterium from Arctic charr are represented by uncultured clinical Neochlamydia sp. sequences obtained from conjunctival cytobrush samples of a cat with ocular disease (von Bomhard et al. 2003). Researchers have referred to chlamydia from these sources as medically relevant environmental chlamydia (von Bomhard et al. 2003, Collingro et al. 2005). Results from Arctic charr suggest that these Neochlamydia spp. sequences may be recoverable from a broader range of clinical samples than previously anticipated. To our knowledge, this may be the first clinically relevant chlamydial sequence to be identified from both a mammalian and piscine source. This serves to expand our understanding of the impact environmental chlamydia can have on clinical chlamydiology and highlights the need to characterize these agents further by determining their host ranges and clinical relevance.

Acknowledgements. We thank Dr. D. McGrogan for histopathology and Dr. P. Cooke for electron microscopy done in earlier outbreaks. We are grateful to J. Wen and V. Han for expert assistance in electron microscopy. We thank C. Marshall for technical support. The experimental protocol and methods described are in compliance with the Animal Welfare Act (9CFR) requirements and are approved by the Freshwater Institute's Institutional Animal Care and Use Committee. This research was funded by the US Department of Agriculture, Agriculture Research Service, under Agreement No. 59-1930-1-130, and by grants from the University of Connecticut Research Foundation, the USDA Cooperative State Research, Education and Extension Service, the Storrs Agricultural Experiment Station, and the Connecticut Sea Grant College Program.

\section{LITERATURE CITED}

Altschul SF, Gish W, Miller W, Myers EW, Lipman DJ (1990) Basic local alignment search tool. J Mol Biol 215:403-410

Altschul SF, Madden TL, Schäffer AA, Zhang J, Zhang Z, Miller W, Lipman DJ (1997) Gapped BLAST and PSIBLAST: a new generation of protein database search programs. Nucleic Acids Res 25:3389-3402

Amann RI, Springer N, Schonhuber W, Ludwig W, Schmid EN, Muller KD, Michel R (1997) Obligate intracellular bacterial parasites of acanthoamoebae related to Chlamydia spp. Appl Environ Microbiol 63:115-121

Avakyan AA, Popov VL (1984) Rickettsiae and chlamydiae: comparative electron microscopic studies. Acta Virol 28: 159-173

Bradley TM, Newcomer CE, Maxwell KO (1988) Epitheliocystis associated with massive mortalities of cultured lake trout Salvelinus namaycush. Dis Aquat Org 4:9-17

Brown C (1998) In situ hybridization with riboprobes: an overview for veterinary pathologists. Vet Pathol 35:159-167

Collingro A, Poppert S, Heinz F, Schmitz-Esser S, Essig A, Schweikert M, Wagner M, Horn M (2005) Recovery of an environmental chlamydia strain from activated sludge by co-cultivation with Acanthamoeba sp. Microbiology (Read) 151:301-309

Corsaro D, Greub G (2006) Pathogenic potential of novel chlamydiae and diagnostic approaches to infections due to these obligate intracellular bacteria. Clin Microbiol Rev 19:283-297

Corsaro D, Venditti D (2004) Emerging chlamydial infections. Crit Rev Microbiol 30:75-106

Crespo S, Zarza C, Padrós F, Marín de Mateo M (1999) Epitheliocystis agents in sea bream Sparus aurata: morphological evidence for two distinct chlamydia-like developmental cycles. Dis Aquat Org 37:61-72

Culling CFA (1974) Handbook of histopathological and histochemical techniques, 3rd edn. Butterworths, Boston, MA

Deveraux LN, Polkinghorne A, Meijer A, Timms P (2003) Molecular evidence for novel chlamydial infections in the koala (Phascolarctos cinerus). Syst Appl Microbiol 26: 245-253

Draghi A II, Popov VL, Kahl MM, Stanton JB, Brown CC, Tsongalis GJ, West AB, Frasca S Jr (2004) Characterization of 'Candidatus Piscichlamydia salmonis' (Order Chlamydiales), a chlamydia-like bacterium associated with epitheliocystis in farmed Atlantic salmon (Salmo salar). J Clin Microbiol 42:5286-5297

Dumler JS, Walker DH (2005) Order II. Rickettsiales Giezczykiewicz, 1939, 25AL emend. In: Brenner DJ, Krieg NR, Staley JT (eds) Bergey's manual of systematic bacteriology, 2nd edn, Vol 2, The Proteobacteria, Part C, The Alpha-, Beta-, Delta-, and Epsilonproteobacteria. Springer, New York, p 96-145

Dumler JS, Barbet AF, Bekker CPJ, Dasch GA, Palmer GH, Ray SC, Rikihisa Y, Rurangirwa FR (2001) Reorganization of genera in the families Rickettsiaceae and Anaplasmataceae in the order Rickettsiales: unification of some species of Ehrlichia with Anaplasma, Cowdria with Ehrlichia and Ehrlichia with Neorickettsia, descriptions of six new species combinations and designation of Ehrlichia equi and 'HGE agent' as subjective synonyms of Ehrlichia phagocytophila. Int J Syst Evol Microbiol 51:2145-2165

Engel JN, Ganern D (1987) Chlamydial rRNA operons: gene organization and identification of putative tandem promoters. J Bacteriol 169:5678-5685

Everett KDE, Andersen AA (1997) The ribosomal intergenic spacer and domain I of the 23S rRNA gene are phylo- 
genetic markers of Chlamydia spp. Int J Syst Bacteriol 47: 461-473

Everett KDE, Bush RM, Andersen AA (1999) Emended description of the order Chlamydiales, proposal of Parachlamydiaceae fam. nov. and Simkaniaceae fam. nov. each containing one monotypic genus, revised taxonomy of the family Chlamydiaceae, including a new genus and five new species, and standards for the identification of organisms. Int J Syst Bacteriol 49:415-440

Felsenstein J (1985) Confidence limits on phylogenies: an approach using the bootstrap. Evolution 39:783-791

Fritsche TR, Horn M, Wagner M, Herwig RP, Schleifer KH, Gautom RK (2000) Phylogenetic diversity among geographically dispersed Chlamydiales endosymbionts recovered from clinical and environmental isolates of Acanthamoeba spp. Appl Environ Microbiol 66: 2613-2619

Gan FY, Luk GD, Gesell MS (1994) Nonradioactive in situ hydridization techniques for routinely prepared pathology specimens and cultured cells. J Histotechnol 17:313-319

Gimenez DF (1964) Staining rickettsiae in yolk-sac cultures. Stain Technol 39:135-140

Groff JM, LaPatra SE, Munn RJ, Andersen ML, Osburn BI (1996) Epitheliocystis infection in cultured white sturgeon (Acipenser transmontanus), antigenic and ultrastructural similarities of the causative agent to the chlamydiae. J Vet Diagn Investig 8:172-180

Hillis DM, Dixon MT (1991) Ribosomal DNA: molecular evolution and phylogenetic inference. Q Rev Biol 66: 411-446

Hoffman GL, Dunbar CE, Wolf K, Zwillenberg LO (1969) Epitheliocystis, a new infectious disease of the bluegill (Lepomis macrochirus). Antonie Leeuwenhoek 35:146-158

Horn M, Wagner M (2001) Evidence for additional genuslevel diversity of Chlamydiales in the environment. FEMS Microbiol Lett 204:71-74

Horn M, Wagner M, Muller KD, Schmid EN, Fritsche TR, Schleifer KH, Michel R (2000) Neochlamydia hartmannellae gen. nov., sp. nov. (Parachlamydiaceae), an endoparasite of the amoeba Hartmannella vermiformis. Microbiology (Read) 146:1231-1239

Ito S, Rikihsa Y (1981) Techniques for electron microscopy of rickettsia. In: Burgdorfer W, Anacker RL (eds) Rickettsiae and rickettsial diseases. Academic Press, New York, p 213-227

Kahane S, Everett KDE, Kimmel N, Friedman MG (1999) Simkania negevensis strain Z: growth, antigenic and genome characteristics. Int J Syst Bacteriol 49:815-820

Lewis EJ, McLaughlin SM, Bodammer JE, Sawyer TK (1992) Epitheliocystis in ten new host species of marine fish. J Fish Dis 15:267-271

Löbau S, Mamat U, Brabetz W, Brade H (1995) Molecular cloning, sequence analysis, and functional characterization of the lipopolysaccharide biosynthetic gene $k d t A$ encoding 3-deoxy-alpha-D-manno-octulosonic acid transferase of Chlamydia pneumoniae strain TW-183. Mol Microbiol 18:391-399

McDowell EM, Trump BF (1976) Histologic fixatives suitable for diagnostic light and electron microscopy. Arch Pathol Lab Med 100:405-406

Editorial responsibility: David Bruno, Aberdeen, UK
Meijer A, Roholl PJM, Ossewaarde JM, Jones B, Nowak BF (2006) Molecular evidence for association of chlamydiales bacteria with epitheliocystis in leafy seadragon (Phycodurus eques), silver perch (Bidyanus bidyanus), and barramundi (Lates calcarifer). Appl Environ Microbiol 72: $284-290$

Noble AC, Wolf JC, Bullock GL, Smith SA, Tsukuda S, Bebak J (1999) Case history: gill pathologies associated with acute and chronic mortalities in Arctic charr (Salvelinus alpinus) cultured in a semi-closed recycle system. In: Cipriano R (ed) Proc 24th Annu Eastern Fish Health Workshop. US Geological Survey, Kearneysville, WV, p 5

Nowak BF, Clark A (1999) Prevalence of epitheliocystis in Atlantic salmon, Salmo salar L., farmed in Tasmania, Australia. J Fish Dis 22:73-78

Nowak BF, LaPatra SE (2006) Epitheliocystis in fish. J Fish Dis 29:573-588

Nylund A, Kvenseth AM, Isdal E (1998) A morphological study of the epitheliocystis agent in farmed Atlantic salmon. J Aquat Anim Health 10:43-55

Palumbi SR (1996) Nucleic acids. II. The polymerase reaction. In: Hillis DM, Moritz C, Mable BK (eds) Molecular systematics, 2nd edn. Sinauer Associates, Sunderland, MA, p 205-248

Palys T, Nakamura LK, Cohan FM (1997) Discovery and classification of ecological diversity in the bacterial world: the role of DNA sequence data. Int J Syst Bacteriol 47: $1145-1156$

Paperna I (1977) Epitheliocystis infection in wild and cultured sea bream (Sparus aurata) and greymullets (Liza ramada). Aquaculture 10:169-176

Pettersson B, Andersson A, Leitner T, Olsvik O, Uhlen M, Storey C, Black CM (1997) Evolutionary relationships among members of the genus Chlamydia based on 16S ribosomal DNA analysis. J Bacteriol 179:4195-4205

Rourke AW, Davis RW, Bradley TM (1984) A light and electron microscopic study of epitheliocystis in juvenile steelhead trout, Salmo gairdneri Richardson. J Fish Dis 7: 301-309

Sheehan DZ, Hrapchak BB (1980) Theory and practice of histotechnology. Bettelle Press, Columbus, $\mathrm{OH}$

Swofford DL (2000) PAUP*: phylogenetic analysis using parsimony ( ${ }^{*}$ and other methods). Sinauer Associates, Sunderland, MA

Thao M, Baumann L, Hess JM, Falk BW, Ng JCK, Gullan PJ, Baumann P (2003) Phylogenetic evidence for two new insect-associated chlamydia of the family Simkaniaciae. Curr Microbiol 47:46-50

Thompson JD, Gibson TJ, Plewniak F, Jeanmougin F, Higgins DG (1997) The CLUSTAL_X Windows interface: flexible strategies for multiple sequence alignment aided by quality analysis tools. Nucleic Acids Res 25:4876-4882

von Bomhard W, Polkinghorne A, Lu ZH, Vaughan L, Vögtlin A, Zimmermann D, Spiess B, Pospischil A (2003) Detection of novel chlamydiae in cats with ocular disease. Am J Vet Res 64:1421-1428

Wolke RE, Wyand DS, Khairallah LH (1970) A light and electron microscopy study of epitheliocystis disease in the gills of Connecticut striped bass (Morone saxitilis) and white perch (Marone americanus). J Comp Pathol 80:559-563

Submitted: August 25, 2006; Accepted: December 28, 2006 Proofs received from author(s): May 28, 2007 